\title{
Reduction of Heavy Metals in Tannery Waste Water using High Voltage Discharge
}

\author{
Md. Rasel Mia \\ EEE department \\ Daffodil International \\ University, \\ Bangladesh
}

\author{
Md. Fayzur Rahman \\ EEE Department \\ Daffodil International \\ University, Bangladesh
}

\author{
Md. Hasanuzzaman \\ EEE department \\ Daffodil International \\ University, \\ Bangladesh
}

\author{
Tasrina Rabia \\ Choudhury \\ Chemistry Division, \\ Atomic Energy Centre \\ Dhaka, Bangladesh
}

\begin{abstract}
Nowadays wastewater is the threat to the environment. There are many source of wastewater. Among them tannery industry is an important source. Various types of chemicals used in tannery industry are liable for the water pollution that makes the river water unfit to the aquatic lives. These river water mingled with wastewater is again supplied in many cities for drinking water by treatment process. Chlorination process for the water treatment is very popular but it does not recede the heavy metals from the wastewater completely. In addition to it there is produced the cancer genic Threehelometens compound for long-term chlorination treatment. These problems can be easily overcome using ozonized gas. For the purpose, it has been designed and implemented a new rectangular shaped type Ozonizer based on silent discharge and surface discharge operation following streamer breakdown principal in our laboratory. The ozonized gas produced from the oxygen gas at first time and then air supplied by air blowerhas been used to dwindle the heavy metals lead $(\mathrm{Pb})$, chromium $(\mathrm{Cr})$ and copper $(\mathrm{Cu})$. Using Flame Atomic Absorption Spectrometry Technique, the amounts of heavy metals in the Tannery wastewater have been measured $0.25[\mathrm{mg} / \mathrm{L}], 16.18[\mathrm{mg} / \mathrm{L}[$ and $0.04[\mathrm{mg} / \mathrm{L}]$ before treatment and $0.14[\mathrm{mg} / \mathrm{L}], 3.89[\mathrm{mg} / \mathrm{L}]$ and 0.03 $[\mathrm{mg} / \mathrm{L}]$ after treatment for the lead, chromium and copper successively. The decreasing amounts of the lead, chromium and copper in the wastewater have also measured by $44 \%, 76$ $\%$ and $25 \%$ successively.
\end{abstract}

\section{General Terms}

Flame Atomic Absorption Spectrometry, Ozonizer, Silent discharge, Surface discharge, Streamer breakdown, Tannery Wastewater.

\section{Keywords}

Flame Atomic Absorption Spectrometry, Ozonizer, Silent discharge, Surface discharge, Streamer breakdown, Tannery Wastewater

\section{INTRODUCTION}

An Ozonizer is a type of air or water purifier, which uses ozone to kill bacteria, virus and filter out a wide range of harmful contaminants from the wastewater by oxidization process. Ozone itself is a form of oxygen $\left(\mathrm{O}_{2}\right)$, though much less stable than the common oxygen $\left(\mathrm{O}_{2}\right)$ gas. Ozone $\left(\mathrm{O}_{3}\right)$ is present naturally, mostly in the upper levels of the atmosphere, where it helps to deflect the ultraviolet radiation. Its main advantages to use as a water purifier is the oxidized compounds do not produce any toxic products during the biodegradation and the excess ozone gas is converted into Oxygen gas quickly. Then after many years of using chlorine in water disinfection process, it was concluded that its usage in potable water treatment could be harmful for human health. For instance, Threehalometanes, produced in such way, are cancer genic compounds. Therefore, The World Health Organization recommended the use of Ozone in water treatment process and some of more developed countries have already started to use ozone in portable water treatment. In our country, there are different industries including sugar, textile and tannery industries that cause environmental pollution through wastewater. About 300 factories in the three designated industrial areas in the capital and Gazipur have long been running without Effluent Treatment Plants (ETPs) causing serious environmental pollution, reports UNB. According to the DoE, there are nearly 200 factories inHazaribagh Tannery area, 46 inShyampur-Kadamtoli industrial area and 42 factories in Bangladesh Small and Cottage Industries Corporation (BSCIC) area, Tongi. These factories discharge untreated chemical wastes into water bodies, polluting the canals and rivers with dumping wastes [1]. In order to purify the tannery wastewater with environmental safety in our country, it has been proposed a new rectangular shaped type ozonizer in our laboratory. Before going to describe the design technique of the proposed ozonizer, we would like to introduce the various factors i.e. gas breakdown, breakdownmechanism, Paschen's law etc. on which the ozonizer performance depends.

\section{BREAKDOWN OF THE GAS IN THE OZONE CHAMBER}

To produce the ozonized gas from our proposed ozonizer, the oxygen gas and air are used. To form the ozonized gas in the ozone chamber, oxygen molecules (pure form or in the air) must be broken down into excited oxygen atoms by high voltage discharge based on dielectric barrier discharge or silent discharge and surface discharge simultaneously. During the formation of the breakdown, the various phenomena i.e. silent discharge, surface discharge and streamer breakdown occur in gaseous dielectrics when a high voltage is applied between the two electrodes immersed in oxygen or air gaseous medium, the oxygen or air gas becomes a conductor and an electrical breakdown occurs through the gas. The processes that are primarily responsible for the breakdown of the gas are ionization by collision, photo-ionization, and the secondary ionization processes that includes the electron emission from the cathode due to positive ions, photon, metastable and neutral atoms [2]. In addition to it, to accelerate the ionization process for more energized electrons to hit the oxygen molecules during the ozonized gas production in the ozonizer, it has also taken the advantages of the corona effect [3] in our research. The practical view of the 
gas breakdown in our laboratory is shown in the following figure.

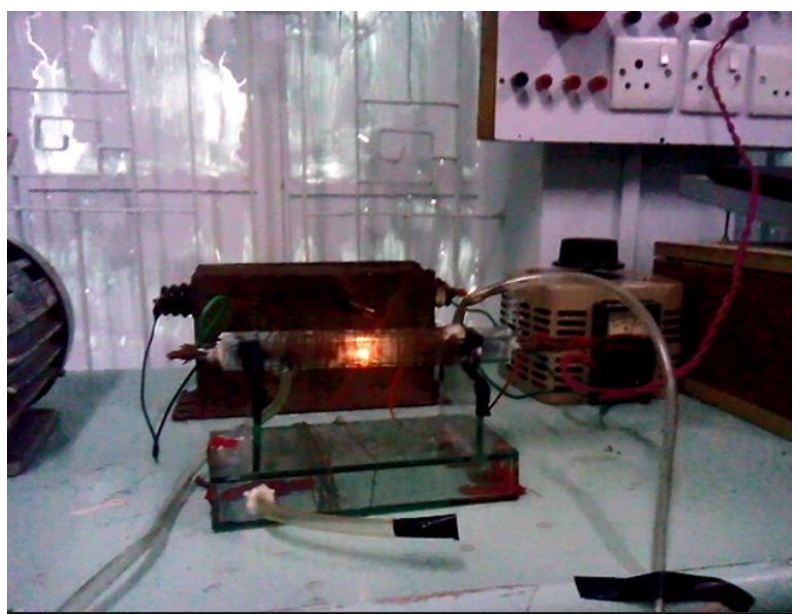

Fig 1: Breakdown of the gas in the ozone chamber in our laboratory

\section{BREAKDOWN MECHANISM OF THE GAS}

To produce the ozonized gas from our proposed ozonizer, it does never undergoes the breakdown of the gas but it is necessary to bring the gaseous medium near to the breakdown level for getting the high energetic electrons to ionize the oxygen molecules into excited oxygen atoms. At present, there are two mechanisms in the world to illustrate the breakdown of the gas. These mechanisms are known as Townsend and Streamer breakdown mechanism. These are described as below.

\subsection{Concept of Townsend Breakdown Mechanism}

One of the breakdownprocesses is the Townsend breakdown mechanism [4]. It is also known as avalanche breakdown mechanism. It is based on the generation of successivesecondaryavalanches to produce breakdown. Suppose a free electron exists (caused by some external effect such as radioactivity or cosmic radiation) in a gas where an electric field exists. If the field strength is sufficiently high, then it is likely to ionize a gas molecule by simple collision resulting in two free electrons and a positive ion. These two electrons will be able to cause further ionization by collision leading in general to four electrons and three positive ions. The process is cumulative and the number of free electrons will go on increasing as they continue to move under the action of the electric field. The swarm of electrons and positive ions produced in this way is called an electron avalanche. In the space of a few millimeters, it may grow until it contains many millions of electrons. This phenomenon is shown in the following figure.

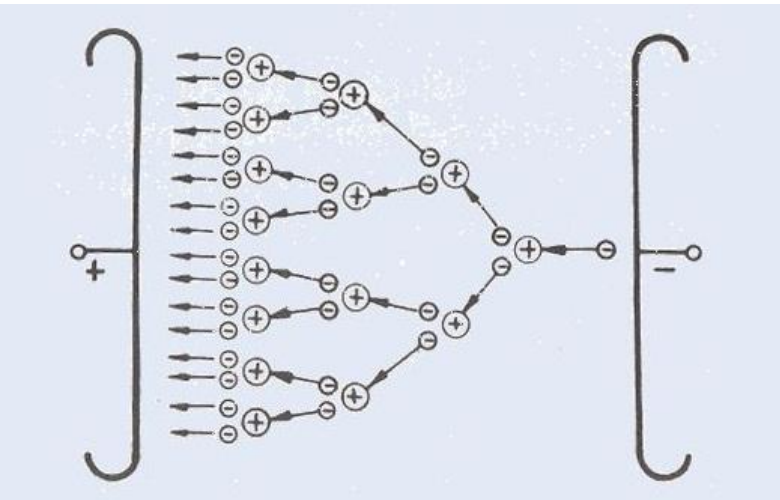

Fig 2: Townsend's breakdown

\subsubsection{Drawback of Townsends Breakdown}

The drawback [2] of the Townsend Breakdown Mechanism is written as below:

Firstly, according to the Townsend theory, current growth occurs because of ionization processes only. However, in practice, breakdown voltages were found to depend on the gas pressure and the geometry of the gap.

Secondly, the mechanism predicts time lags of the order of $10^{-5} \mathrm{~s}$, while in actual practice breakdown was observed to occur at very short times of the order of $10^{-8} \mathrm{~s}$.

In addition, while the Townsend mechanism predicts a muchdiffused form of discharge, in actual practice, discharges were found to be filamentary and irregular. The Townsend mechanism failed to explain all these observed phenomena

\subsection{Streamer Breakdown Mechanism}

Notice from the Townsend breakdown mechanism that this theory cannot explain some practical phenomenon mentioned in the drawback of Townsend breakdown mechanism. To avoid this confliction around 1940, Raether, Meek, and Loeb independently proposed the Streamer breakdown theory [2].

The theory predicts the development of a spark discharge directly from a single avalanche in which the space charge developed by the avalanche itself and explains the transformation of the avalanche into a plasma streamer.

Suppose an electron produced by photo ionization close to the cathode starts the avalanche phenomena in the gaseous medium.

Being so fast electron then positive ion, electrons reach the anode compared to positive ions that virtually stay its original position. As a result, more positive charged ions occupy the space near the anode forming head to tail streamer between the anode and cathode as figure 3(a). At this time, the electric field is increased and a secondary avalanche is also produced due to some electrons created by photoionization in the space charged region and the produced positive ions extend towards the cathode. This phenomenon is shown in figure 3(b). When the tail of the streamer touches the cathode, a large number ofelectrons rush into the streamer from the cathode to neutralize the positive ions in the streamer. Now in the streamer there are available positive ions and electrons simultaneously. As a result, this streamer is converted into plasma state and become a conductingmedium for the electrons. This phenomenon is also shown in the figure 3(c). In the streamer break down, a large number of narrow luminous tracks are simultaneously created from the whole 
length of the cathode, whose diameter is $100 \mu \mathrm{m}$ to $200 \mu \mathrm{m}$. Thus, a large number of micro discharge or streamers are raised from the cathode to anode as fig.4 [5].

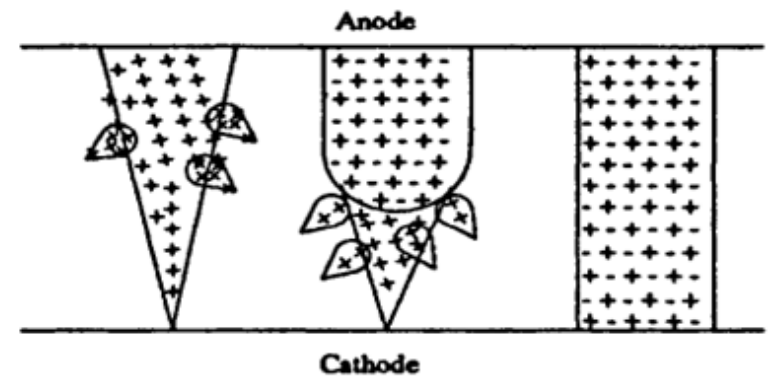

(a)

(b)

(c)

Fig 3: Formation of streamer

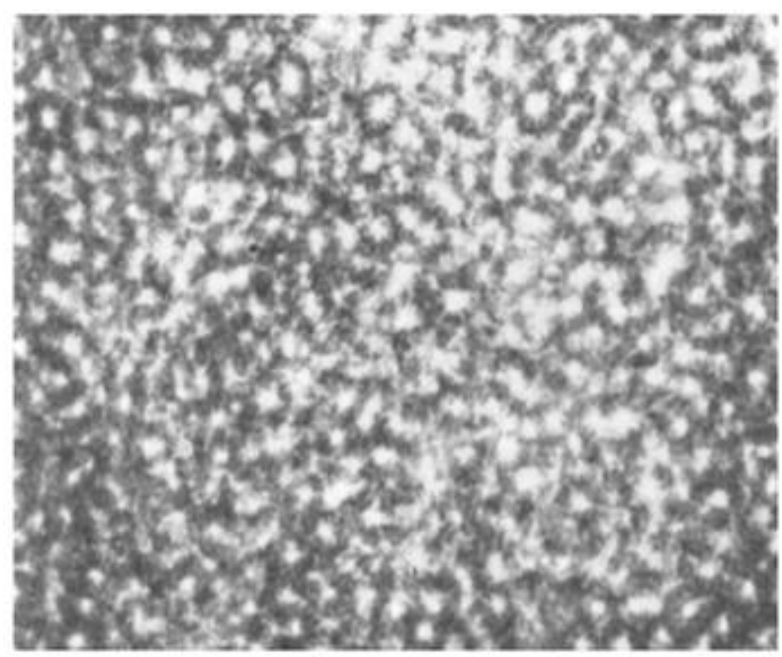

Fig 4: Microscopic view of streamer

\section{PASCHEN'S LAW}

When electrons and ions move through a gas in a uniform field $\mathrm{E}$ and gas pressure $\mathrm{p}$, their mean energies attain equilibrium values depending on the ratio $\mathrm{E} / \mathrm{p}$ from where the Paschen's Law can be derived as below:

$$
f_{2}\left(\frac{v}{p d}\right)\left[e^{\left\{p d f_{1}\left(\frac{v}{p d}\right)\right\}-1}\right]=1
$$

This equation shows the relationship between $v$ and $p d$ and implies that the breakdown voltage varies as the product of $p d$ varies, knowing the nature of function $f_{1}$ and $f_{2}$ we can write,

$\mathrm{v}=\mathrm{f}(\mathrm{pd})$.

This equation is known as Paschen's law[2] and has been established for many gases and it will be very helpful to understand the performance of our proposed ozonizer.

The minimum breakdown voltages and the relationships between $\mathrm{V}$ and $p d$ [2] are shown in Table 1 and Fig.5according to the Paschen's law.
Table 1. Minimum sparking potential voltage for various gases

\begin{tabular}{|c|c|c|}
\hline Gas & $\begin{array}{c}v_{S} \text { minimum } \\
\text { breakdown } \\
\text { voltage (v) }\end{array}$ & $\begin{array}{c}p d \text { at minimum } v_{s} \\
\text { (torr.cm) }\end{array}$ \\
\hline Air & $\mathbf{3 2 7}$ & $\mathbf{0 . 5 6 7}$ \\
\hline Argon & 137 & 0.9 \\
\hline $\mathrm{H}_{2}$ & 273 & 4.15 \\
\hline Helium & 156 & 0.51 \\
\hline $\mathrm{CO}_{2}$ & 420 & 0.67 \\
\hline $\mathrm{N}_{2}$ & 251 & 0.5 \\
\hline $\mathrm{N}_{2} \mathrm{O}$ & 418 & $\mathbf{0 . 7}$ \\
\hline $\boldsymbol{O}_{2}$ & $\mathbf{4 5 0}$ & 0.33 \\
\hline $\mathrm{SO}_{2}$ & 457 & 0.6 \\
\hline $\mathrm{H}_{2} \mathrm{~S}$ & 414 & \\
\hline & & \\
\hline
\end{tabular}

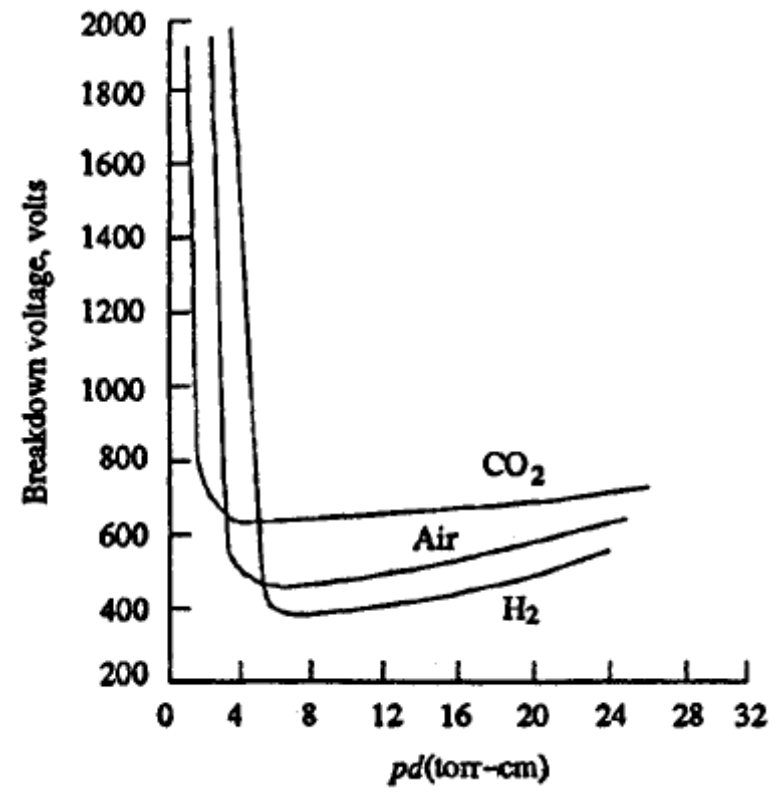

Fig 5: Breakdown voltage - pd(torr-cm)

The sparking potentials for uniform field gaps in air, $\mathrm{CO}_{2}$ and $\mathrm{H}_{2}$ at $20^{\circ} \mathrm{C}$ are shown in Fig 5.

For values of $p d>p d_{\text {min }}$, electrons crossing the gap make more frequent collisions with gas molecules than at $p d_{\text {min }}$, but the energy gained between collisions is lower. Hence, to maintain the desired ionization more voltage has to be applied.

For $p d<p d_{\text {min }}$, electron may cross the gap without even making a collision or making only less number of collisions. Hence, more voltage has to be applied for breakdown to occur. 
Therefore, from the above curve, we can say that for the more energetic electron to ionize the oxygen gas molecules, the gaseous medium is treated under the streamer breakdown mechanism, which occurs above the value of pressure times discharge gap about 327 volt for air gas and about 450 volt for oxygen gas of this page for three addresses. If only one address is needed, center all address text. For two addresses, use two centered tabs, and so on. For three authors, you may have to improvise.

\section{DESIGN OF OUR PROPOSED OZONIZER}

So far, we have studied the required factors to design an ozonizer on which the performance of the ozonizer depends.Now we discuss the criteria and parameters to design our proposed new rectangular shaped type ozonizer based on corona effect principle:

\subsection{Internal Electrode(s) Shape}

In our proposed ozonizer, there have been used two shorted internal electrode(s) and a solenoid outer electrode wrapped around the ozonizer. Let us consider the discharge gap between the internal electrode(s) and the outer electrode is D $[\mathrm{mm}]$, the thickness of the Belgium glass (available in Bangladesh) plate is $X[\mathrm{~mm}]$ and the radius of the internal electrode (s) is R [mm] shown in the Fig 6.

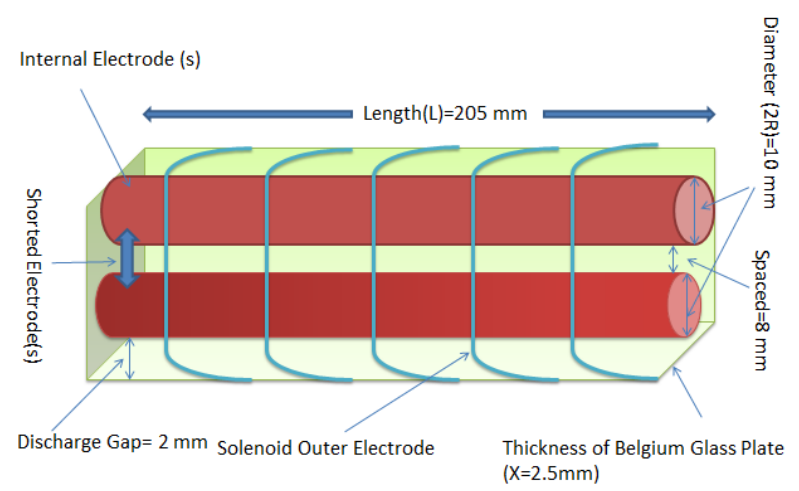

Fig 6: Schematic diagram of a proposed ozonizer

If we now apply the high $\mathrm{AC}$ voltage between the internal electrode (s) and the outer electrode consider the voltage across the gas gap is $v_{g}$, the voltage across the dielectric glass box is $v_{d}$, electric field in gas and dielectric glass is $E_{g}$ and $E_{d}$ respectively. The potential gradient [3] at the internal electrode (s) surface is given as,

$$
E_{g}=\frac{V_{g}}{R \ln \frac{D}{R}}[\text { volt } / \mathrm{mm}]
$$

In addition to it, the critical disruptive voltage that can initiate the micro discharge or surface discharge is also given by,

$$
V_{g}=E_{0} m_{0} \delta R \ln \frac{D}{R}[\text { volts } / \mathrm{mm}]
$$

Here,

$E_{0}=$ Breakdown strength of air gas at $760[\mathrm{~mm}]$ of mercury and $25^{\circ} \mathrm{C}$

$\delta=$ Air density factor that is equal to 1 at $760[\mathrm{~mm}]$ of mercury and $25^{\circ} \mathrm{C}$

Where $\delta=\frac{3.92 b}{273+t}$ and

$\mathrm{b}=$ Barometric pressure and $\mathrm{t}=$ any temperature.

$m_{0}=$ Surface Irregularity factor where

$m_{0}=1$ for polished conductor

$m_{0}=0.92$ to 0.98 for dirt conductor

$m_{0}=0.8$ to 0.87 for stranded conductor.

Since for $m_{0}=0.8$ to 0.87 value, the breakdown voltage $\left(V_{g}\right)$ from equation (3) is low. Therefore, we choose the stranded conductor for low breakdown voltage or high potential gradient at the internal electrode (S) surface to increase the energy of the electrons.

\subsection{Glass Type}

To produce the ozonized gas, we need to connectthe high voltage through step up transformer to two electrodes i.e. internal electrode and outer electrode protected by glass plate. During the production of ozonized gas, a much heat is generated. This heat reduces the rate of formation of ozonized gas. Therefore, to increase the rate of formation of ozonized gas the generated heat is transferred through the closed glass box. For this reason, the glass box must be transparent and withstand to heat. For this purpose, Pyrex glass is appropriate but in our country, the customized Pyrex glass is not available. Therefore,

We have accepted a Belgium glass to make our proposed ozonizer.

\subsection{Thickness of Belgium Glass Plate}

Again, the potential gradient at the dielectric glass box is given as,

$$
E_{d}=\frac{V_{d}}{D \ln \frac{X+D}{D}}[\text { volts } / \mathrm{mm}]
$$

in addition, the voltage across the dielectric barrier is also given by,

$$
V_{d}=E_{d} D \ln \frac{X+D}{D}[\text { volts } / \mathrm{mm}]
$$

It is noticeable from equation (1) that potential gradient at the internal electrode (S) surface does not depend on the thickness (X) of the dielectric barrier but it (dielectric barrier) can affect the voltage $V_{g}$ or $V_{d}$. Therefore, from equation (5), we can see that if we increase the thickness $X$ of the dielectric barrier keeping others parameters at fixed value the voltage across the dielectric barrier (glass) is increased. As a result, the voltage across the gas gap, which can initiate the Streamer Breakdown of the gas medium, becomes low that may not initiate enough discharge. Therefore, we have to choose the less thickness of the glass, which has been accepted about 2.5 $[\mathrm{mm}]$ in our design.

\subsection{Discharge Gap}

From equation (2), we can see that if we decrease the discharge gap (D) the potential gradient at the stranded internal electrode (s) surface will be high which is very important to start the breakdown of oxygen gas to form the ozonized gas for no uniform electric field.Again, the breakdown voltage equation according to the Paschen's law for the uniform electric field is repeated as below:

$$
V_{b d}=f(P D)
$$


So, from equation (5) or (1) for both no uniform and uniform electric field we can see that if we decrease the discharge gap (D) value the breakdown voltage will be low for that gas.

From the Table 1, the minimum spark voltage at $p d=0.567$ torr.cm for air is 327 volt or at $p d=0.7$ torr.cm, minimum breakdown voltage for oxygen gas is 450 volt and more value of $p d$ ( $p d>0.567$ torr. $\mathrm{cm}$ ) theelectron avalanche will be high. For the value, $p d>1000$ torr.cm the air gas breakdown follows the streamer breakdown mechanism in which those electrons gain enough energy to ionize the Oxygen atoms. So for the value of $p d=1200$ torr $\mathrm{cm}$ at pressure $(6000$ torr $\cong 8$ atm.) the discharge gap is calculated as,

$\mathrm{D}=\frac{\boldsymbol{P D}(\text { torr } . \boldsymbol{c m})}{\boldsymbol{P}(\text { torr })}, \mathrm{D}=0.2[\mathrm{~cm}]=2[\mathrm{~mm}]$

So this low discharge gap $\mathrm{D}=2[\mathrm{~mm}]$ the potential gradient at the internal electrode(s) surface is also increased largely.

\subsection{Radius of the Internal Electrode}

From equation (2) Or (3), we can see that if we increase the value of $\operatorname{Radius}(\mathrm{R})$ of the internal electrode (s) the potential gradient at the internal electrode(s) surface will be high or breakdown voltage ofthe gas will be low respectively. Therefore, we have chosen the value of Radius (R) about, $\mathrm{R}=5[\mathrm{~mm}]$.

\subsection{Length of the Internal Electrode(s)}

In order the Oxygen molecules to breakdown; we need more high-energized electrons. High-energized electrons can be developed following streamer breakdown or from filamentary streamer. Increasing the length of the internal electrode (s) we can increase the number of filamentary streamer or micro discharge but simultaneously more heat is produced that causes the unstable of newly formed ozone gas. Therefore, we have chosen the length of the internal electrode (s) about, $\mathrm{L}=$ $205[\mathrm{~mm}]$.

\section{WORKING PRINCIPLE}

The ozone gas is produced in the discharge gap of the ozonizerusing oxygen gas. Since the $p d$ value ( $p d=1200$ [torr.cm]) where $p$ is the pressure about 6000 [torr] and $d$ is the discharge gap, is greater than 1000 [torr.cm] in our research so the streamer breakdown of the oxygen gas is occurred in the ozonizer. Verifying the applied high AC voltage the number of the micro discharge can be affected rather than the transferred charge through the micro discharge. The greater the applied voltage the greater the number of the filamentary micro discharge and faster the breakdown of the gas. We can also reduce the breakdown voltage of the gas by increasing the frequency of the voltage signal. With increasing the frequency of the applied voltage, the accumulated memory voltage on the dielectric layer is also increased simultaneously. As a result, the avalanched electrons gain high energy enough to break down the gas travelling through a large amount of micro discharge streamer produced from the various points of the internal electrode(s). The excited electrons then dissociate the oxygen gas molecules into excited oxygen atoms. This oxygen atoms are tiedtogether to form the ozonized gas as the following chemical reactions [6] in the ozonizer.

$$
\begin{gathered}
\mathrm{o}_{2}+e^{-}=o+o+e^{-} \\
\mathrm{o}_{2}+e^{-}=o(3 p)+o(3 p)+e^{-}
\end{gathered}
$$

$$
\begin{gathered}
\mathrm{o}_{2}+e^{-}=o(1 D)+\mathrm{o}(3 \mathrm{p})+e^{-} \\
o+o_{2}+M=o_{2}+M
\end{gathered}
$$

Where $\mathrm{M}$ is the third collision part but if the supplied oxygen gas contains any moisture, the moisture decomposes the ozonized gas according to the following reactions,

$$
\begin{gathered}
\mathrm{H}_{2} \mathrm{O}+\mathrm{O}_{3}=\mathrm{O}_{2}+\mathrm{H}_{2} \mathrm{O}_{2} \\
\mathrm{H}_{2} \mathrm{O}_{2}=\mathrm{H}+\mathrm{HO}_{2} \\
\mathrm{HO}_{2}+\mathrm{O}_{3}=2 \mathrm{O}_{2}+\mathrm{OH} \\
\mathrm{OH}+\mathrm{O}_{3}=\mathrm{O}_{2}+\mathrm{HO}_{2}
\end{gathered}
$$

Therefore, the supplied gas is kept away from the moisture and the temperature to improve the efficiency of the ozonizer. This ozonized gas is brought through the bottom channel of the ozonizer into the wastewater. To mingle the produced ozonized gas with the wastewater we have moved the pot containing wastewater with stick or hand sometimes.

\section{BLOCK DIAGRAM}

To produce the ozone gas, all apparatus are connected to each other in our laboratory as per the following block diagram:

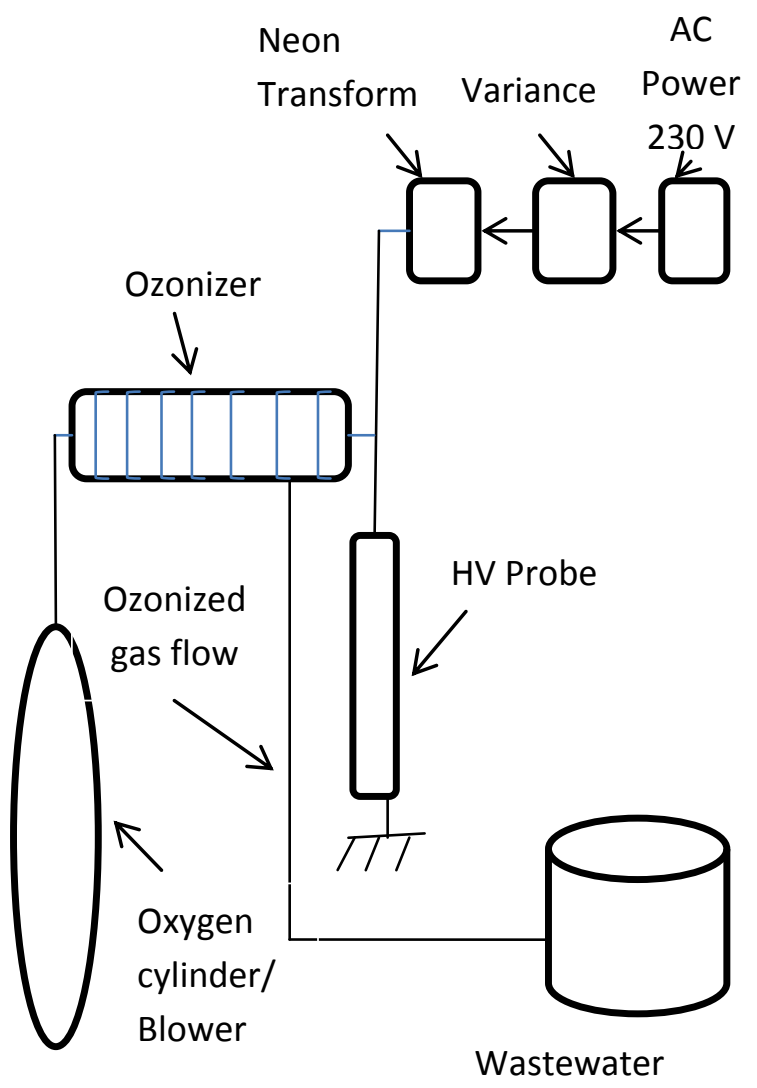

Fig 7: Block diagram of full set of equipment's

\section{TREATMENT PROCEDURE}

On the purpose of the reduction of heavy metals in the Tannery wastewater by our proposed ozonizer, two leads from 
the external and the internal electrode of the ozonizer are connected to the secondary side of the neon transformer. The primary side of the neon transformer is also connected to the secondary side of the variance where the primary side of the variance is connected to the single-phase AC power supply. To facilitate the oxygen gas flow through the ozone chamber the top channel of the ozonizeris connected with the channel coming from the oxygen cylinder or the air blower and the bottom channel is entered into the small plastic pot containing the sampled wastewater. After full connection of the required equipment's, the power supply switch is on and the airflow is flowed into the ozone chamber. At first, the pure oxygen cylinder was used tofacilitate the oxygen gas flow and second stage the air blower was used to continue the oxygen gas flow into the ozone chamber to produce the ozonized gas. The produced ozonized gas was mixed with the wastewater creating turbulence by airflow or shaking the container by hand.

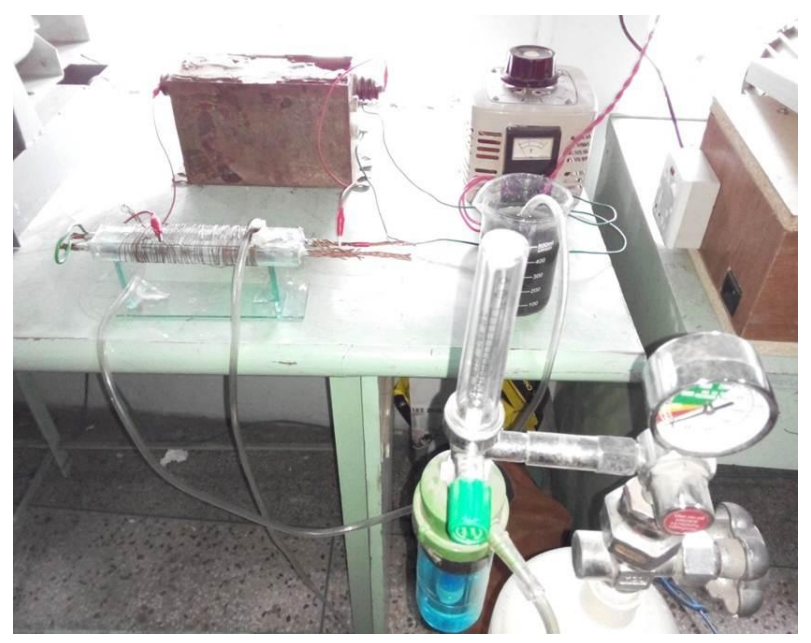

Fig 8: Full set up of equipment's for the wastewater treatment.

The maintained parameters during the ozone treatment are also summarized in the following table.

Table 2. Lists of the maintained parameters during Treatment

\begin{tabular}{|c|c|c|c|c|}
\hline $\begin{array}{c}\text { Serial } \\
\text { No. }\end{array}$ & $\begin{array}{c}\text { Parameters } \\
\text { Name }\end{array}$ & $\begin{array}{c}\text { Technique } \\
\text { Used }\end{array}$ & Reading & $\begin{array}{c}\text { Frequency } \\
{[\mathrm{Hz}]}\end{array}$ \\
\hline 1 & $\begin{array}{c}\text { Applied } \\
\text { voltage to } \\
\text { Ozonizer }\end{array}$ & $\begin{array}{c}\text { Transformer } \\
\text { \& variance } \\
\text { ratings }\end{array}$ & $\begin{array}{c}\text { About } 7 \\
{[\mathrm{KV}]}\end{array}$ & 50 \\
\hline 2 & $\begin{array}{c}\text { Breakdown } \\
\text { Voltage }\end{array}$ & $\begin{array}{c}\text { Transformer } \\
\text { \& variance } \\
\text { ratings }\end{array}$ & $\begin{array}{c}\text { About } \\
10[\mathrm{KV}]\end{array}$ & 50 \\
\hline 3 & $\begin{array}{c}\text { Oxygen } \\
\text { flow }\end{array}$ & $\begin{array}{c}\text { Oxygen } \\
\text { cylinder/ } \\
\text { Blower }\end{array}$ & $\begin{array}{c}10 \\
{[\mathrm{kgf} /} \\
\left.\mathrm{cm}^{2}\right] / \\
1400 \\
{[\mathrm{rpm}]}\end{array}$ & N/A \\
\hline 4 & $\begin{array}{c}\text { Input } \\
\text { voltage } \\
\text { from power } \\
\text { supply }\end{array}$ & Variance & $\begin{array}{c}\text { About } \\
230[\mathrm{~V}]\end{array}$ & 50 \\
\hline 5 & $\begin{array}{c}\text { Input } \\
\text { voltage to } \\
\text { Neon } \\
\text { transformer }\end{array}$ & Variance & $\begin{array}{c}\text { About } \\
175[\mathrm{~V}]\end{array}$ & 50 \\
\hline
\end{tabular}

\begin{tabular}{|c|c|c|c|c|}
\hline 6 & $\begin{array}{c}\text { Treatment } \\
\text { time }\end{array}$ & Stop watch & $\begin{array}{c}\text { About 2 } \\
{[\text { hours] }}\end{array}$ & N/A \\
\hline 7 & $\begin{array}{c}\text { Neon } \\
\text { Transformer }\end{array}$ & $\begin{array}{c}\text { Step up } \\
{[\text { Single }} \\
\text { phase] }\end{array}$ & $\begin{array}{c}230 \mathrm{~V} \\
\sim 11 \mathrm{KV}\end{array}$ & 50 \\
\hline 8 & Variance & $\begin{array}{c}\text { Single } \\
\text { phase }\end{array}$ & $\begin{array}{l}0 \mathrm{~V} \sim \\
230 \mathrm{~V}\end{array}$ & 50 \\
\hline
\end{tabular}

\section{EQUIPMENTS USED IN OUR LABORATORY}

Equipments used in our laboratory to produce the Ozonized gas are described as below:

\subsection{Ozonizer}

It is used to produce the ozonized gas with thehelp of oxygengas using high voltage following the silent and surface discharge principle. It has been made in our laboratory. It has two outlets. One for entering of air located on the top and another is used to bring the ozonized gas out, which is situated at the bottom of the ozonizer as following figure:

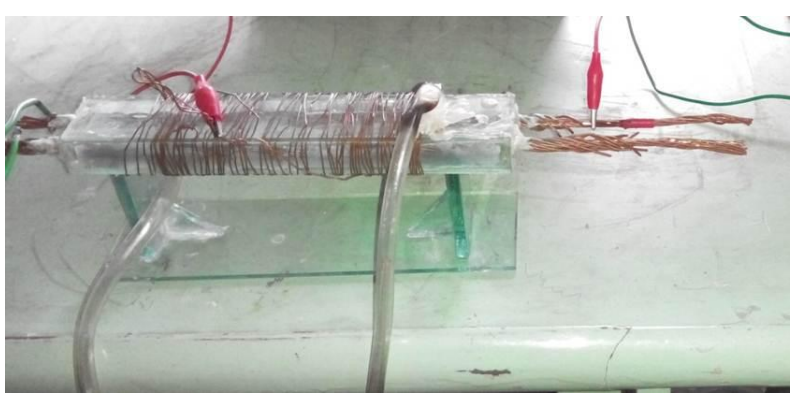

Fig 9: Our proposed ozonizer in our laboratory

\subsection{Voltage Variance}

This device is used to change the input voltage from 0 volt to 266 volt. Changing the voltage using it, we can easily get the required voltage on our research purpose. The voltage Variance is shown in the following figure.

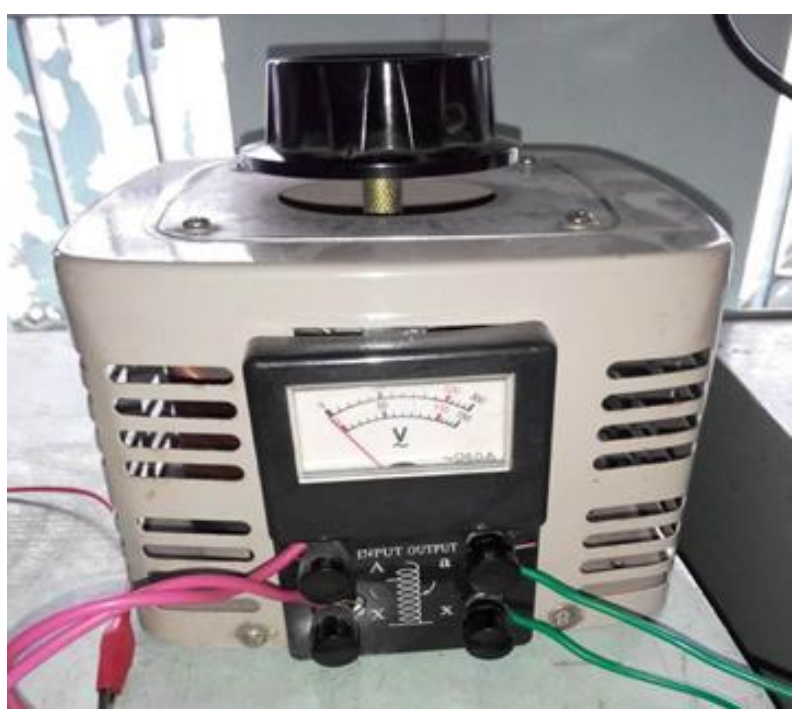

Fig 10: Variance 


\subsection{Neon Transformer}

It is a step up transformer. It stepsthe input voltage up from 0 volt to $11 \mathrm{kV}$. Using this transformer, we can easily apply the required high voltage to the ozonizer.

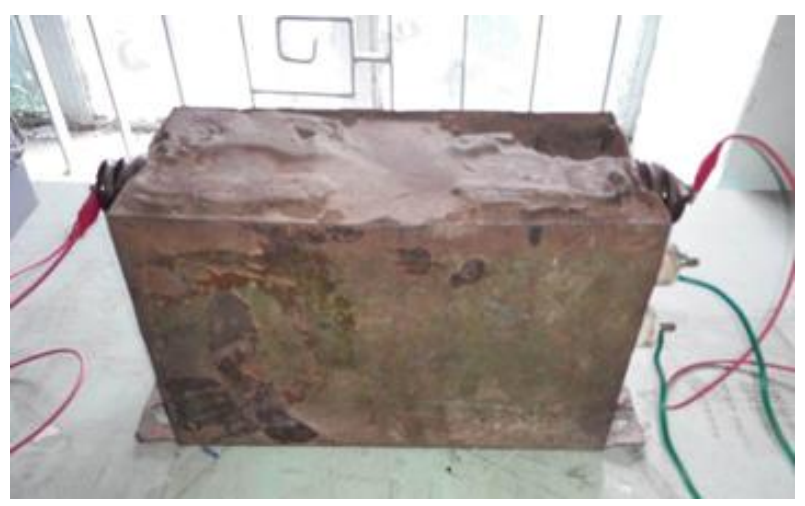

Fig 11: Neon transformer

\subsection{Blower and Oxygen Cylinder}

To flow the oxygen gas into the ozone chamber to produce the ozone gas we have used the oxygen cylinder and the blower to facilitate the oxygen gas flow. These are below:

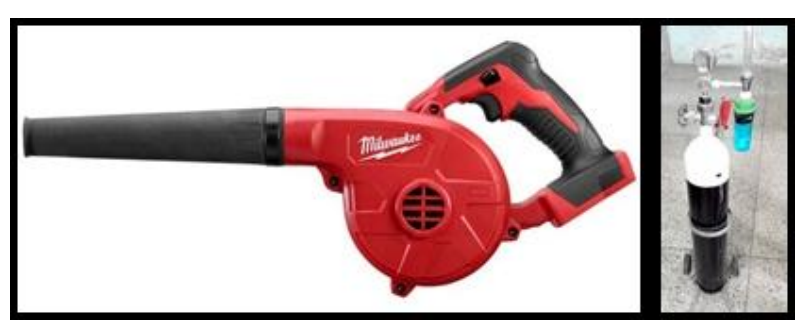

Fig 12: Blower and oxygen cylinder

\subsection{Atomic Absorption Spectrometer}

Flame AtomicAbsorption Spectrometry (FAAS) technique has been used for the quantitative determination of the heavy metals in the pre and post Tannery wastewater i.e. lead $(p b)$, chromium $(\mathrm{Cr})$ and copper $(\mathrm{Cu})$. The technique is an Australian invention that has its origins in the CSIRO in the 1950 's and since then has become well established in laboratories around the world. In essence, flame atomic absorption spectroscopy involves generating a gaseous population of free atoms by heating a sample in a flame and then passing narrow bandwidth light at a certain wavelength through the atoms in the flame. These conditions result in absorption of radiation that is selective for a particular element. The real picture of FAAS in the laboratory is as below:

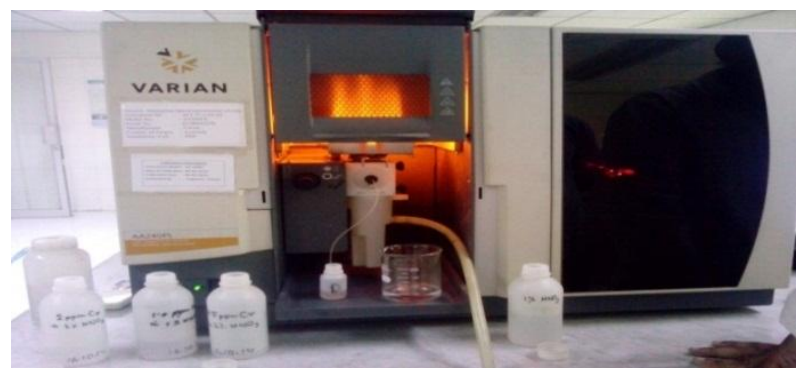

Fig 13: Flame atomic absorption spectrometer (FAAS)

\subsection{Using Parameters of Spectrometer during Chemical Analysis}

During quantitative determination, the value of the heavymetals lead, chromium and copper in the Tannery wastewater in our laboratory were as below:

Table3: List of parameters of FAAS during chemical analysis

\begin{tabular}{|c|c|c|c|}
\hline $\begin{array}{l}\text { Name of } \\
\text { Parameter }\end{array}$ & $p b$ & $\mathrm{Cr}$ & $\mathrm{Cu}$ \\
\hline $\begin{array}{l}\text { Instrument } \\
\text { type }\end{array}$ & Flame & Flame & Flame \\
\hline $\begin{array}{l}\text { Instrument } \\
\text { mode }\end{array}$ & Absorbance & Absorbance & Absorbance \\
\hline $\begin{array}{l}\text { Calibration } \\
\text { mode }\end{array}$ & Concentration & $\begin{array}{c}\text { Concentratio } \\
n\end{array}$ & $\begin{array}{c}\text { Concentratio } \\
n\end{array}$ \\
\hline $\begin{array}{c}\text { Sampling } \\
\text { mode }\end{array}$ & Manual & Manual & Manual \\
\hline $\begin{array}{c}\text { Wavelengt } \\
\mathrm{h}\end{array}$ & $217.0[\mathrm{~nm}]$ & 357.9 [nm] & 324.8 [nm] \\
\hline Slit width & $0.1[\mathrm{~nm}]$ & $0.2[\mathrm{~nm}]$ & $0.5[\mathrm{~nm}]$ \\
\hline Gain & $71 \%$ & $67 \%$ & $70 \%$ \\
\hline $\begin{array}{l}\text { Lamp } \\
\text { current }\end{array}$ & $10[\mathrm{~mA}]$ & $7[\mathrm{~mA}]$ & $4[\mathrm{~mA}]$ \\
\hline $\begin{array}{l}\text { Lamp } \\
\text { position }\end{array}$ & 1 & 1 & 1 \\
\hline Flame type & $\begin{array}{c}\text { Air/ } \\
\text { Acetylene }\end{array}$ & $\begin{array}{c}\text { Air/ } \\
\text { Acetylene }\end{array}$ & $\begin{array}{c}\text { Air/ } \\
\text { Acetylene }\end{array}$ \\
\hline Airflow & $\begin{array}{l}13.50[\mathrm{~L} / \mathrm{min} \\
]\end{array}$ & $\begin{array}{c}13.50 \\
{[\mathrm{~L} / \mathrm{min}]}\end{array}$ & $\begin{array}{c}13.50 \\
{[\mathrm{~L} / \mathrm{min}]}\end{array}$ \\
\hline $\begin{array}{l}\text { Acetylene } \\
\text { flow }\end{array}$ & $2.00[\mathrm{~L} / \mathrm{min}]$ & $2.90[\mathrm{~L} / \mathrm{min}]$ & $2.0 \quad[\mathrm{~L} / \mathrm{min}]$ \\
\hline
\end{tabular}

\section{OZONE REACTIONS WITH HEAVY}

\section{METALS}

Ozone oxidizes most metals (except gold, platinum, and iridium) to their highest oxidation state [7] as below:

$$
\begin{gathered}
\mathrm{Cu}^{+}+\mathrm{O}_{3} \rightarrow \mathrm{Cu}^{2+}+\mathrm{O}_{3}^{-} \\
\mathrm{O}_{3}^{-} \leftrightarrow \mathrm{O}^{-}+\mathrm{O}_{2} \\
\mathrm{O}^{-}+\mathrm{H}_{2} \mathrm{O} \rightarrow \mathrm{OH} \bullet+\mathrm{OH}^{-} \\
\mathrm{OH} \bullet+\mathrm{Cu}^{+} \rightarrow \mathrm{Cu}^{2+}+\mathrm{OH}^{-} \\
\mathrm{OH} \bullet+\mathrm{O}_{3} \rightarrow \mathrm{HO}_{2} \bullet+\mathrm{O}_{2}
\end{gathered}
$$

Or the above reactions of copper $\left(\mathrm{Cu}^{+}\right)$with ozone $\left(\mathrm{O}_{3}\right)$ can be written as below

$$
\mathrm{Cu}^{+}+\mathrm{H}_{2} \mathrm{O}+\mathrm{O}_{3} \rightarrow \mathrm{Cu}^{2+}+2 \mathrm{OH}^{-}+\mathrm{O}_{2}
$$

Similarly chromium and lead react with ozonized gas as following reactions respectively

$$
\mathrm{Cr}^{3+}+\mathrm{H}_{2} \mathrm{O}+\mathrm{O}_{3} \rightarrow \mathrm{Cr}^{6+}+2 \mathrm{OH}^{-}+\mathrm{O}_{2} \text { and }
$$




$$
\mathrm{Pb}^{2+}+\mathrm{H}_{2} \mathrm{O}+\mathrm{O}_{3} \rightarrow \mathrm{Pb}^{3+}+2 \mathrm{OH}^{-}+\mathrm{O}_{2}
$$

These last states of the heavy metals copper, chromium and lead may make the following hydroxide compounds in the waste water during treatment.

$$
\begin{aligned}
& \mathrm{Cu}^{2+}+2 \mathrm{OH}^{-}=\mathrm{Cu}(\mathrm{OH})_{2} \\
& \mathrm{Cr}^{6+}+6 \mathrm{OH}^{-}=\mathrm{Cr}(\mathrm{OH})_{6}
\end{aligned}
$$

And, $\mathrm{Pb}^{3+}+3 \mathrm{OH}^{-}=\mathrm{Pb}(\mathrm{OH})_{3}$

Since these hydroxide compounds are bases so they may react with the carbonic acid created by carbon di oxide plus water $\left(\mathrm{CO}_{2}+\mathrm{H}_{2} \mathrm{O}=\mathrm{H}_{2} \mathrm{CO}_{3}\right)$ or sulphate ions $\left(\mathrm{SO}_{4}{ }^{2-}\right)$ in the waste water to form salts of the metals as following reaction

$$
\begin{aligned}
& \mathrm{Cu}(\mathrm{OH})_{2}+\mathrm{SO}_{4}{ }^{2-} \rightarrow \mathrm{CuSO}_{4}+\mathrm{H}_{2} \mathrm{O} \\
& \mathrm{Cr}(\mathrm{OH})_{6}+\mathrm{SO}_{4}{ }^{2-} \rightarrow \mathrm{Cr}_{2}\left(\mathrm{SO}_{4}\right)_{6}+\mathrm{H}_{2} \mathrm{O} \\
& \mathrm{Pb}(\mathrm{OH})_{3}+\mathrm{CO}_{3}{ }^{2-} \rightarrow \mathrm{Pb}_{2}\left(\mathrm{CO}_{3}\right)_{3}+\mathrm{H}_{2} \mathrm{O}
\end{aligned}
$$

Thus ozonized gas reduces the quantative amount of the heavy metals converting them into correspondind salts in the water which are not harmful to environment or human beings and filtering these salts, the treated water is discharged into river or environment.

\section{OZONE REACTIONS WITH \\ ORGANIC COMPOUNDS}

Organic compounds in the Tannery wastewater include various types of long chained carbon molecules i.e. aldehyde compounds, carboxyl acids, aromatic compounds that are responsible for color change and bad smell of the wastewater. Such widely used organic compounds are Aromaticsulfonic compounds i.e. Naphthalene-1-sulfonic acid (NS), naphthalene-1, 5-disulfonic acid (NDS) and naphthalene-1, 3, 6-trisulfonic acid (NTS). Ozone reacts with this nonbiodegradable compounds making pungent odors, color in water and converts them by breaking down into small biodegradable compounds specially carbon di oxide $\left(\mathrm{CO}_{2}\right)$ and water $\left(\mathrm{H}_{2} \mathrm{O}\right)$ as the main byproduct in the river. The Naphthalene-1-sulfonic acid [8] and azo grouped Direct pink 3B (CI Direct Red 31) [9] reacts with ozonized gas as following chemical reactions.

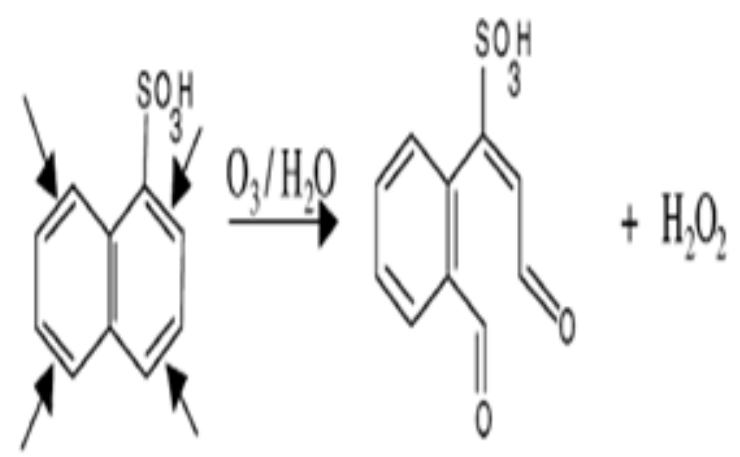

Naphthalene-1-sulfonic acid<smiles>O=C/C=C(\c1ccccc1C=O)S(=O)(=O)O</smiles>

$+\mathrm{O}_{3}=\mathrm{CO}_{2}+\mathrm{SO}_{4}{ }^{2-}(\mathrm{aq})+\mathrm{H}_{2} \mathrm{O}$

$\left(\mathrm{CO}_{2}\right.$ As byproduct $)$

Fig 14: Direct chemical reaction between ozone and naphthalene-1-sulfonic acid

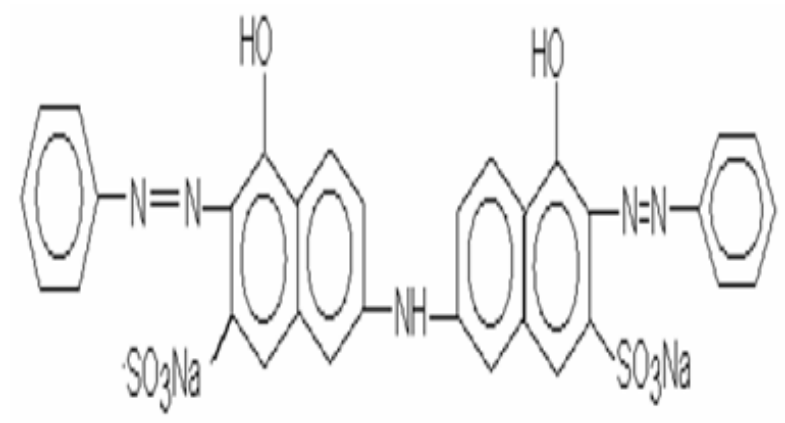

Direct pink 3B (CI Direct Red 31)

$$
+\mathrm{O}_{3} \rightarrow \mathrm{NaSO}_{4}+\mathrm{NaNO}_{3}+\mathrm{CO}_{2}+\mathrm{H}_{2} \mathrm{O}
$$

Fig 15: Direct reaction of ozone with direct Pink 3B

Here naphthalene-1, 5-disulfonic acid (NDS) and naphthalene-1, 3, 6-trisulfonic acid (NTS) dye chemicals react with ozone gas directly and produce the same main byproduct $\left(\mathrm{CO}_{2}+\mathrm{H}_{2} \mathrm{O}\right)$ like Naphthalene-1-sulfonic acid (NS).

So from the above chemical reactions occurred among ozonized gas and the organic compounds, it is seen that all harmful organic compounds are broken-down into carbon di oxide $\left(\mathrm{CO}_{2}\right)$ as the main byproduct which is not dangerous for environment. Thus, the discolor and the pungent smell of the Tannery wastewater due to organic compounds are reduced to a noticeable state.

\section{RESULTS AND DISCUSSIONS}

The main aim of our research on the Tannery wastewater treatment using our proposed ozonized basedtechnique was to reduce the amount of the heavy metals in the wastewater. In addition to it, the color and the pungent smell of the wastewater were also reduced to noticeable state. These are described as below:

\subsection{Reduction of Heavy Metals}

In our research, we haveonly analyzed the heavy metals reduction. The percentages of these heavy metals in the wastewater were reduced by our designed and implemented treatment system with noticeable ratio. The quantitative detection technique of heavy metals was "Flame Atomic Absorption Spectrometry" in the Analytical Chemistry 
laboratory, Chemistry Division at Atomic Energy Centre, Dhaka (AECD). The pre and posttest data with standard deviation of the heavy metals are given in the following table

Table4. List of quantitative amount of heavy metals in the wastewater

\begin{tabular}{|c|c|c|c|c|c|}
\hline $\begin{array}{l}\text { Ser } \\
\text { ial } \\
\text { No. }\end{array}$ & $\begin{array}{l}\text { Sample } \\
\text { Name }\end{array}$ & $\begin{array}{l}\text { Techni } \\
\text { que } \\
\text { used }\end{array}$ & $\begin{array}{l}\text { Lead } \\
(P b) \\
\text { with } \\
\text { stand } \\
\text { ard } \\
\text { deviat } \\
\text { ion } \\
\mathrm{mg} / \mathrm{L}\end{array}$ & $\begin{array}{l}\text { Chrom } \\
\text { ium } \\
(\mathrm{Cr}) \\
\text { with } \\
\text { standa } \\
\text { rd } \\
\text { deviati } \\
\text { on } \\
\mathrm{mg} / \mathrm{L}\end{array}$ & $\begin{array}{l}\text { Copp } \\
\text { er } \\
(\mathrm{Cu}) \\
\text { with } \\
\text { stand } \\
\text { ard } \\
\text { deviat } \\
\text { ion } \\
\mathrm{mg} / \mathrm{L}\end{array}$ \\
\hline 1 & $\begin{array}{l}\text { Tannery } \\
\text { wastewater } \\
\text { (Before } \\
\text { treatment) }\end{array}$ & FAAS & $\begin{array}{l}0.25 \pm \\
0.02\end{array}$ & $\begin{array}{l}\text { 16.18 } \pm \\
0.13\end{array}$ & $\begin{array}{l}0.04 \pm \\
0.002\end{array}$ \\
\hline 2 & $\begin{array}{l}\text { Tannery } \\
\text { wastewater } \\
\text { (after } \\
\text { treatment) }\end{array}$ & FAAS & $\begin{array}{l}0.14 \pm \\
0.01\end{array}$ & $\begin{array}{l}\text { 3.89 } \pm \\
0.05\end{array}$ & $\begin{array}{l}0.03 \pm \\
0.01\end{array}$ \\
\hline
\end{tabular}

The following table also gives the detection limits of the heavy metals for Flame Atomic Absorption Spectrometer (FAAS):

Table 5. List of detection limits of the heavy metals

\begin{tabular}{|c|c|c|c|c|}
\hline $\begin{array}{c}\text { Serial } \\
\text { N0. }\end{array}$ & $\begin{array}{l}\text { Technique } \\
\text { used }\end{array}$ & $\begin{array}{l}\text { Lead } \\
(P b) \\
\mathrm{mg} / \mathrm{L}\end{array}$ & $\begin{array}{l}\text { Chromium } \\
(\mathrm{Cr}) \mathrm{mg} / \mathrm{L}\end{array}$ & $\begin{array}{c}\text { Copper } \\
(\mathrm{Cu}) \\
\mathrm{mg} / \mathrm{L}\end{array}$ \\
\hline 1 & FAAS & 0.02 & 0.013 & 3.0 \\
\hline
\end{tabular}

- $\quad$ FAAS: Flame Atomic Absorption Spectrometry After treatment, the decreasing amounts of the heavy metals in the Tannery wastewater are also determined from table 4.as below:

Table6. Decreasing amounts of the heavy metals after treatment in percentage

\begin{tabular}{|l|l|l|l|l|}
\hline $\begin{array}{l}\text { Serial } \\
\text { No. }\end{array}$ & $\begin{array}{l}\text { Name of } \\
\text { wastewater }\end{array}$ & $\begin{array}{c}\text { Lead } \\
(\mathrm{Pb}) \\
{[\%]}\end{array}$ & $\begin{array}{l}\text { Chromium } \\
(\mathrm{Cr})[\%]\end{array}$ & $\begin{array}{l}\text { Copper } \\
(\mathrm{Cu}) \\
{[\%]}\end{array}$ \\
\hline 1 & $\begin{array}{l}\text { Tannery } \\
\text { wastewater }\end{array}$ & $\mathbf{4 4 \%}$ & $\mathbf{7 6} \%$ & $\mathbf{2 5 \%}$ \\
\hline
\end{tabular}

Therefore, from the above table 4 or table 6 we can see that after treatment the heavy metals amount in the Tannery wastewater have been reduced to a noticeable state.

In addition to it, the following table also gives the allocation limits of the heavy metals in the Island/ River water according to the "The Environment Conservation Rules 1997, DoE, Bangladesh"can be shown for the comparison of the reduced amount of heavy metals in the wastewater as below:
Table 7.Allocation limits of the heavy metals in Island

\begin{tabular}{|c|c|c|c|c|}
\hline \multirow[t]{2}{*}{$\begin{array}{c}\text { Serial } \\
\text { No. }\end{array}$} & \multirow[t]{2}{*}{$\begin{array}{c}\text { Disposal } \\
\text { sources }\end{array}$} & \multicolumn{3}{|c|}{$\begin{array}{l}\text { Standard limits of the heavy } \\
\text { metals in Island water/ River } \\
\text { water according to the } \\
\text { Environmental Conservation } \\
\text { Rules 1997, DoE, Bangladesh }\end{array}$} \\
\hline & & $\begin{array}{l}\text { Lead } \\
(P \boldsymbol{b}) \\
\mathrm{mg} / \mathrm{L}\end{array}$ & $\begin{array}{c}\text { Chromium } \\
\qquad \begin{array}{c}(C r) \\
\mathrm{mg} / \mathrm{L}\end{array}\end{array}$ & $\begin{array}{l}\text { Coppe } \\
\mathbf{r} \\
(\mathrm{Cu}) \\
\mathrm{mg} / \mathrm{L}\end{array}$ \\
\hline 1 & $\begin{array}{l}\text { Island } \\
\text { water/ } \\
\text { River } \\
\text { water }\end{array}$ & 0.1 & 0.5 & 0.5 \\
\hline
\end{tabular}

So comparing the reduced amount of the heavy metals in the Table 4 to the amounts in the Table 7, we see that the amount of lead $(p b)$ in the Tannery wastewater after treatment was about $0.14 \pm 0.01 \mathrm{mg} / \mathrm{L}$ with standard deviation, which is near to the allowable limit $0.1 \mathrm{mg} / \mathrm{L}$ of the River water. The amount of Chromium $(\mathrm{Cr})$ with standard deviation in the Tannery wastewater after treatment was about $3.89 \pm 0.05$ $\mathrm{mg} / \mathrm{L}$ which is above the permissible limit $0.5 \mathrm{mg} / \mathrm{L}$ in the River water and the Copper $(\mathrm{Cu})$ amount with standard deviation in the tannery wastewater after treatment was about $0.03 \pm 0.01 \mathrm{mg} / \mathrm{L}$ that is below then allowable limit $0.5 \mathrm{mg} / \mathrm{L}$ in the River water.

From the above data, it is seen that the reduced amount of the heavy metals in the wastewater after treatment are above or below then the permissible limit of the metals in the river water. However, in our research, the main goal is to reduce the quantitative amount of the heavy metals in the wastewater only and we have been success in this case.

\subsection{Color Change}

In our research, it has been noticed thatthe color and the bad smell of the Tannery wastewater has also been reduced after treatment based on ozonized gas. We know that the maximum organic compounds are responsible for the color change of the wastewater. Since the color of the wastewater have been reduced so it is concluded that the organic compounds in the wastewater have been broken down into carbon di oxide $\left(\mathrm{CO}_{2}\right)$ and water $\left(\mathrm{H}_{2} \mathrm{O}\right)$ as the main byproduct according to the reaction discussed previously. For that reason, the color of the wastewater has been changed to a noticeable state as the following Picture. The color change of the Tannery wastewater after ozonizationis shown in the following figure. 


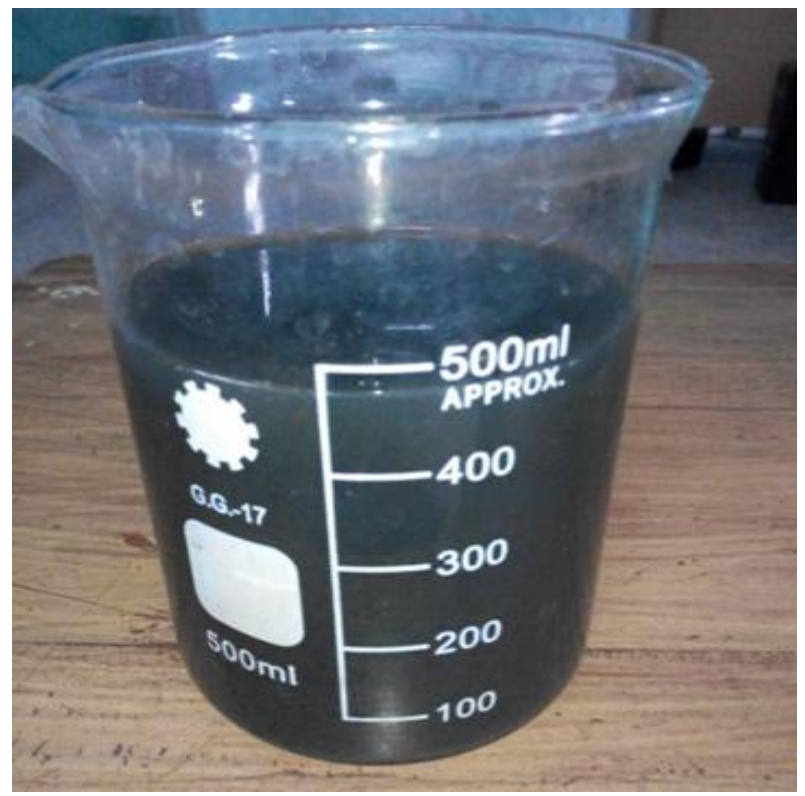

Fig 14: Tannery wastewater before treatment

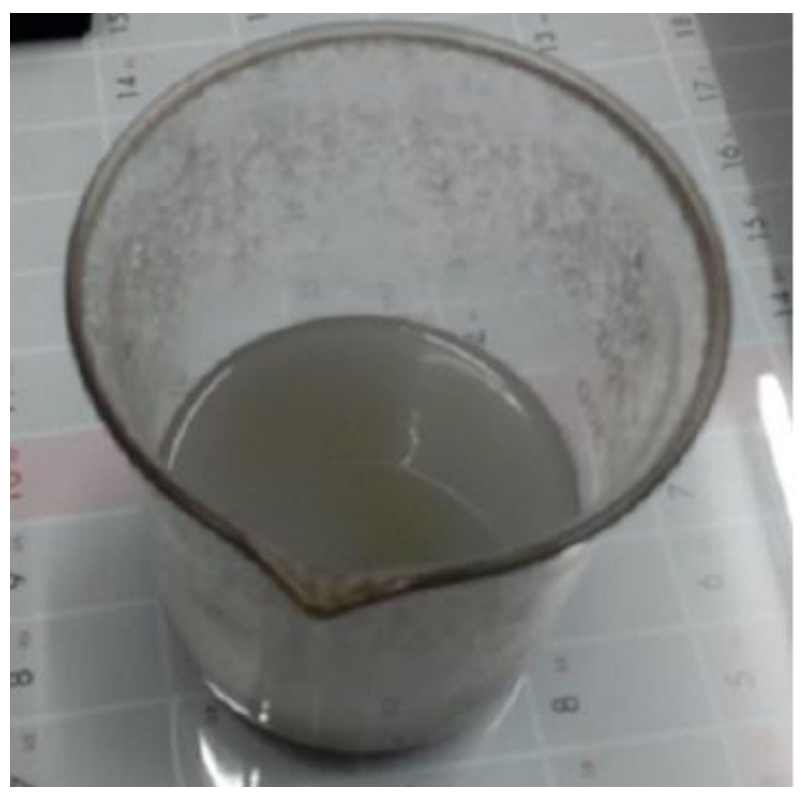

Fig 15: Tannery wastewater after treatment

\subsection{Reduction of Pungent Smell}

We know that the organiccompounds in the Tannery wastewater are also responsible for the bad smell, which are non-biodegradable. Theoretically we have seen that the organic compounds are broken down into carbon di oxide $\left(\mathrm{CO}_{2}\right)$ and water $\left(\mathrm{H}_{2} \mathrm{O}\right)$ as the final byproduct in the chemical reaction among ozonized gas and the organic compounds.In other words, the organic compounds making bad smell are not existed in the wastewater after treatment.For this reason, the pungent smell of the Tannerywastewater was also reduced to a noticeable state.

\section{CONCLUSION}

1. The ozonization process is very powerful tool, environment friendly and safe to treat the different types of wastewater.
2. This process does not produce any toxic materials as byproduct during biodegradable unlike chlorination process used in the water treatment plant, which generates the "Cancer genic Threehelometanse" compound as byproduct.

3. In this system, excess ozonized gas is discomposed into oxygen gas in the water very quickly.

4. Using Flame Atomic Absorption Spectrometry technique, the decreased amount of lead $(p b)$ in the Tannery wastewater samples are found about $44 \%$.

5. The decreased amount of chromium (Cr) in the Tannery wastewater samples are observed about $76 \%$.

6. The decreased amount of copper $(\mathrm{Cu})$ in the Tannery wastewater samples are also found about $25 \%$.

7. The bad smells, color of the wastewater have also been reduced to the noticeable state. In addition to it, the bacteria and virus in the wastewater can also be killed following the ozonized process in a short time.

8. The problem of mixing of ozonized gas with the wastewater is still a challenging task. Special membrane can be developed to perform this and more research work is required in this case.

\section{ACKNOWLEDGEMENT}

At first, we express our cordial gratefulness to the almighty Allah for kindness and divine blessing that makes it possible to complete our thesis work successfully.We also feel happy to share the helpful and warm encouragement of our friends and all staffs of our laboratoryespecially Md. AzizulMaksud, Md. ShahidurRahman and Lutfun NaharLutfa.

\section{REFERENCES}

[1] The Independent daily newspaper report on Saturday 10 January 2015. Source UNB

[2] M.S Naidu and V Kamaraju "HIGH VOLTAGE ENGINEERING".

[3] V.K Mehta "Power system analysis" (Chapter 8).

[4] HV_Chap1.pdf

[5] Jose L. Lopez, Saint Peter's College" Dielectric Barrier Discharge, Ozone Generation and their Applications. Complex Plasmas Summer Institute 2008"

[6] Md. FayzurRahman, H. J. Song, S. G. Lee, W. Z. Park, K. S. Lee, D. I. Lee, "Effect on the Change On Electrode Construction In A Superposed Discharge Type Ozonizer," Proc. of the J-K Symp., KIT, Kita-Kyushu, Japan, pp. 220-223, Oct. 25-26., 1999.

[7] ElinaPortjanskaja, "OZONE REACTIONS WITH INORGANIC AND ORGANIC COMPOUNDS IN WATER"

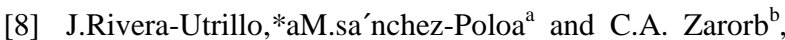
"Degradation of naphthalene sulfonic acids by oxidation with ozone in aqueous phase"

[9] Hoda Roushdy Guendy,"Ozone Treatment of Textile Wastewater Relevant to Toxic Effect Elimination in Marine Environment "Egyptian Journal of Aquatic Research Vol.33 No.1, 2007: 98-115" 